\title{
Experience and Prospects of a Shielding in the Implementation of Works on the Transformation of the Shelter Object into an Ecologically Safe System
}

Keywords:

radiation protection, shielding, Shelter object, sources of ionizing radiation.

\begin{abstract}
The efficiency of the use of personnel protection shielding against intensive sources of ionizing radiation in the areas of work at the Shelter object is analyzed. Data on the practical application of protective shields when performing works to stabilize unstable structures of the Shelter object are presented. The models for the use of special protective cabins for the dismantlement of the Shelter object structures are justified; these models are planned to be implemented after the commissioning of the New Safe Confinement. It is shown, that use of shielding as one of the most effective methods for reducing the collective dose of radiation is crucial.
\end{abstract}

\section{Introduction}

A lot of work on the transformation of the Shelter object into an ecologically safe system was carried out in severe radiation-hazardous environments and required the implementation of a number of protective measures. Since the beginning of the 2000s, a large amount of construction and installation works have been implemented at the Shelter object. Most of the work was carried out in places with the presence of intense sources of ionizing radiation. Shielding measures were used to protect the personnel who performed work under such conditions. Such protective measures were implemented during the implementation of the project on stabilizing of beams B1 and B2, stabilizing of the structures of the Shelter object, creating of a protective contour of a New Safe Confinement (NSC), etc. The most widely used shields and protective cabins were used to carry out works to strengthen the Western support of the "Mammoth" beam, as well as the cementation of the soils of the local area of the Shelter object by a cement-aqueous mixture [1]. Specific requirements for shields for each working area were proposed in the working project - geometric sizes, thickness and mass.
The Institute for Safety Problems of the Nuclear Power Plants (ISP NPP) of the National Academy of Sciences of Ukraine participated in the development of the projects, as well as carried out author's supervision of its implementation. As a result, the project data was accumulated, based on which the justification for the need for protection was made, as well as the actual results of the received radiation doses of personnel and data on the practical effectiveness of the protection.

Taking into account the experience gained, ISP NPP was involved in the design works on the dismantling of the Shelter object designs. According to [2] dismantling of its structures will start shortly after the commissioning of the NSC, therefore [3] work should be completed by the end of 2023.

\section{Research methodology}

The main source of data for mathematical modeling of geometry, sizes and characteristics of shielding means are the angular distribution of gamma radiation intensity in space $(4 \pi)$ using the device ShD-1 and data experimental shielding at a specific workplace by means of protection simulation device the "Ekran". To evaluate the effectiveness 
of the protective shields methodology and data presented in $[4,5]$ were used. Initial data for calculations (dose rate, characteristics of the energy spectrum, the presence and properties of intense sources of ionizing radiation) were obtained as a result of comprehensive survey of workplaces at the Shelter object [6].

\section{Results and discussion}

The presence of intensive sources of ionizing radiation in the areas of work at the Shelter object required the development of special shielding solutions in the stabilization of beams B1 and B2, which were implemented in 1999. The purpose was to prevent the collapse of beams, which could lead to a drop of pipe rolling on the overlap of the central hall, scheme E, etc. The risk of such an incident was the possibility of the release of a significant amount of highlevel radioactive dust outside the Shelter object.
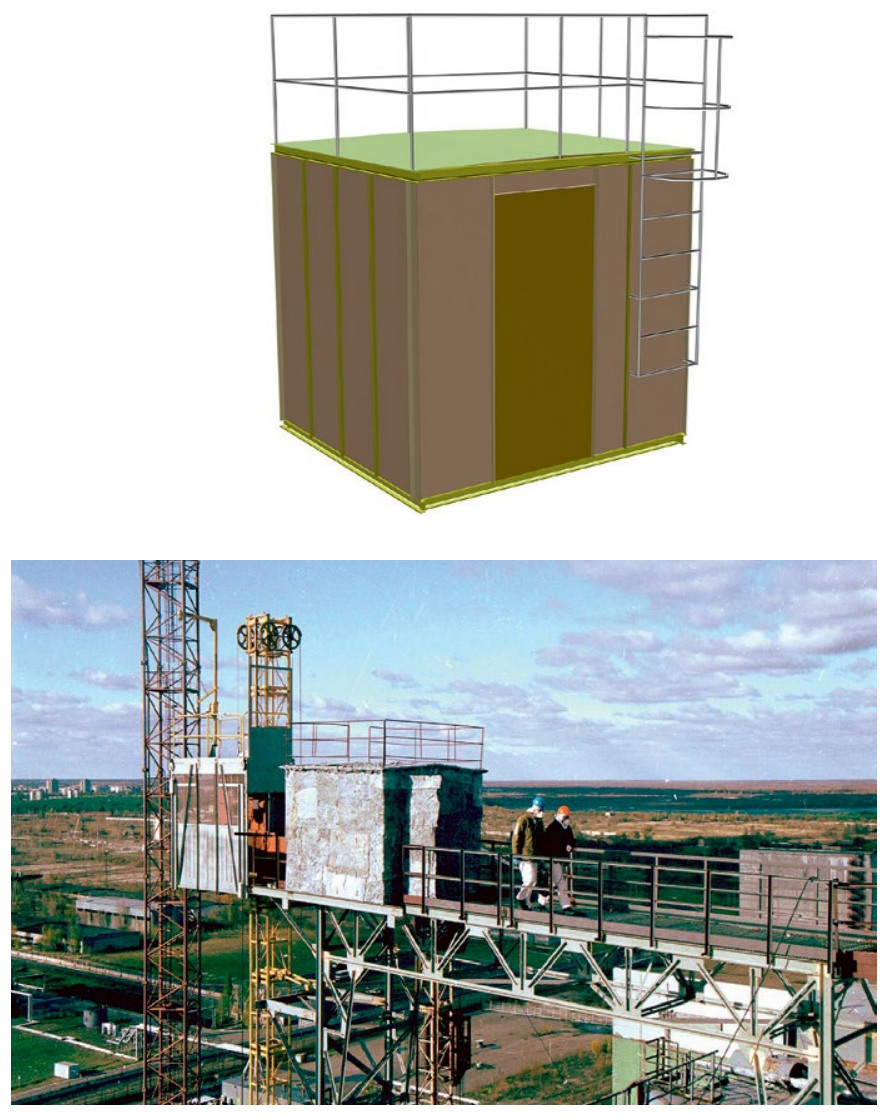

Fig. 1. Design and practical use of the shielded cabin

However, the work on the support nodes of the beams were significantly complicated by the high levels of gamma radiation from the major conglomeration of radioactive materials in the reactor unit. In this regard, one of the shielding solutions was the creation of a protective cabin. Fig. 1 shows a graphic design of the cab and a picture of the cabin during the work. The use of such device allowed to reduce significantly the number of personnel per 100 people involved in the project and reduce the collective dose of radiation by $1.1 \mathrm{~Sv}$ [2].

During the works on stabilization of the unstable structures at the Shelter object, the main protective measures were applied in the following areas of work: the western bearing of the "Mammoth" beam, the northern counterfort wall, the foundations of beams B1 and B2, the console part of the reinforcement steel structures, the position of openings in the western counterfort wall, staff access route on the southern shields.

Particular attention was paid to the use of protective structures, such as protective box, shielded cabins, shielded carriage. For example, during the cementation of the base for metal reinforcement structures of the western wall of the Shelter object, cabins and special shields for radiation protection of drill master's workstations and workers involved in well drilling and cementation of the base were developed and implemented. The protective cabin consisted of a frame of metal profiles, which formed a bulk structure of $1040 \times 1040 \times 2520 \mathrm{~mm}$. The roof and tray of the cab were covered with steel sheets, and two wall sides were lined with lead sheets $10 \mathrm{~mm}$ thick. According to the design calculations, a collective dose without shielding in the implementation of such measures as the strengthening of the western support of the beams "Mammoth", work on the area of the northern fronts, work in the area of the site of the clamping on the wall of beams B1 and B2, as well as the cost of access routes amounted to 19.2 people $\times \mathrm{Sv}$. When using protective shielding, the collective dose was 14.8 people $\times$ Sv. Thus, the collective dose was reduced to 4.4 people $\times \mathrm{Sv}$.

During the project of the Shelter object structures stabilization, based on the "dose-cost-benefit" analysis, it was decided to create a protective wall in the area of the site of the enlarged assembly. The site was located in the local area of the Shelter object and it needs protection from the eastern side against intense sources of ionizing radiation. The protective wall (Fig. 2) was arranged with blocks of $36.6 \mathrm{~m}$ length, $9.6 \mathrm{~m}$ high and $400 \mathrm{~mm}$ thick.

According to the calculations, the reduction of value gamma radiation after the construction of the protective wall is 2.5 times. After the construction, the actual effectiveness of the protective wall was measured and it was found that, depending on the place of measurement, the coefficient of reduction of value gamma radiation is 1.8-3.2 times. Comparison of the design values with the actual levels of attenuation allows to conclude that the 
design decisions are correct, it allowed to reduce the dose rates at workplaces on the site more than 2 times.

Important actions for the protection of personnel were performed during the work on the transfer of loading from beams B1 and B2 into metal reinforcement structures. Radiological conditions in the areas of work required the use of shields, since the dose rate was in the range of 0.1 to $0.4 \mathrm{~Sv} / \mathrm{h}$. Reducing the dose rate after the shielding of workplaces has confirmed the justification of its use when performing stabilization project at the Shelter object.

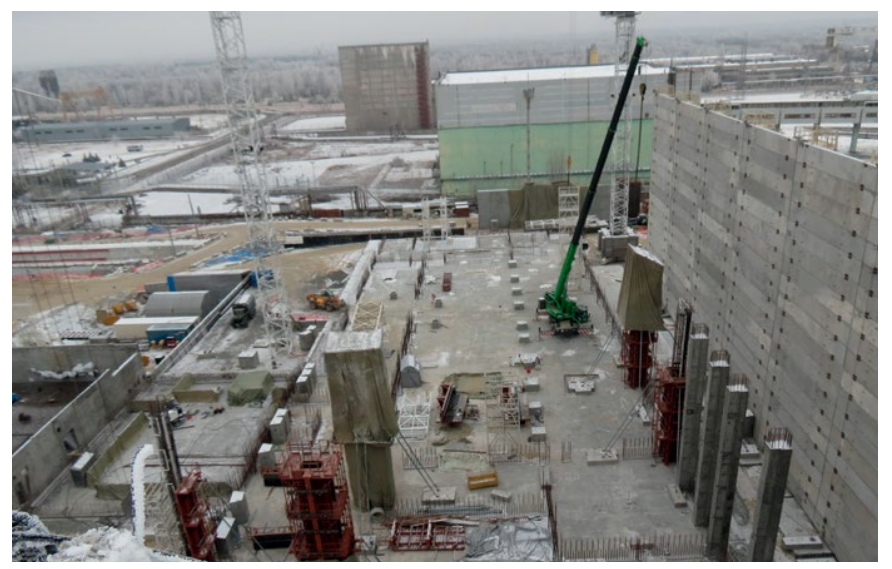

Fig. 2. Protective wall at the Shelter object site

The ISP NPP also participated in works on the creation of the NSC enclosing perimeter. The Institute carried out works connected with the removal of shields and metal roofing panels, the removal of the wall panels of the end of the turbine hall and other work. For part of the work, a need for the development of protective actions was determined. Therefore, for the dismantling of the roofing panels of the turbine hall between the axes 64-66, A-B, a decision to use horizontal shielding of the type of protective overlapping platforms and shielded stairs was taken. As a protective material, lead sheets with 5-10 $\mathrm{mm}$ in thickness were chosen.

Radiation conditions in the work areas, namely, during work on the removal of shielding for an additional roof of the turbine hall, as well as metal roofing panels of the turbine hall with the help of tower cranes, can be characterized as complex conditions. In this case, existing sources of ionizing radiation affect both the personnel working on the roof, and the operators of the tower cranes. In this regard, the project envisaged shielding cabs of tower cranes, in which operators are inside for a relatively long time. Protection with sheet lead is provided to reduce the dose rate in the cockpit tower cranes. It is known from the experience of work on the implementation of projects at the Shelter object, that the dose rate in the cockpit of construction machinery can be reduced four times by shielding. The final decision on the cabins' shielding was taken after agreement with the company manufacturer of cranes.

According to the Strategy, the dismantling of the Shelter object must begin shortly after the commissioning of the NSC. At the moment, scientists of Chornobyl NPP has developed a pilot project "Reconstruction of the Shelter object of the Chornobyl NPP. Demolition of a steelwork for strengthening the southern roof" [7]. Researchers of the ISP NPP have analyzed and substantiated use of the protective shields in the workplace related to the demolition of the steelwork and the strengthening of the staff's access routes. Analysis of the radiation conditions in the work area showed that the value of gamma radiation reaches $0.5 \mathrm{~Sv} / \mathrm{h}$. However, the installation of stationary bioprotection shields is not profitable. On the other hand, an analysis of possible access routes to the southern shields has shown that it is most appropriate to organize the access of personnel to the area of work with the help of a special shielded cabin (Fig. 3), which will be served through the NSC main cranes system. A cabin can be used also to protect personnel against exposure gammaradiation during forced technological breaks. According to the calculations, the effective/or equivalent dose rate in the shielded cabin should not exceed $25 \mathrm{mSv} / \mathrm{h}$ when placed on the southern roof.

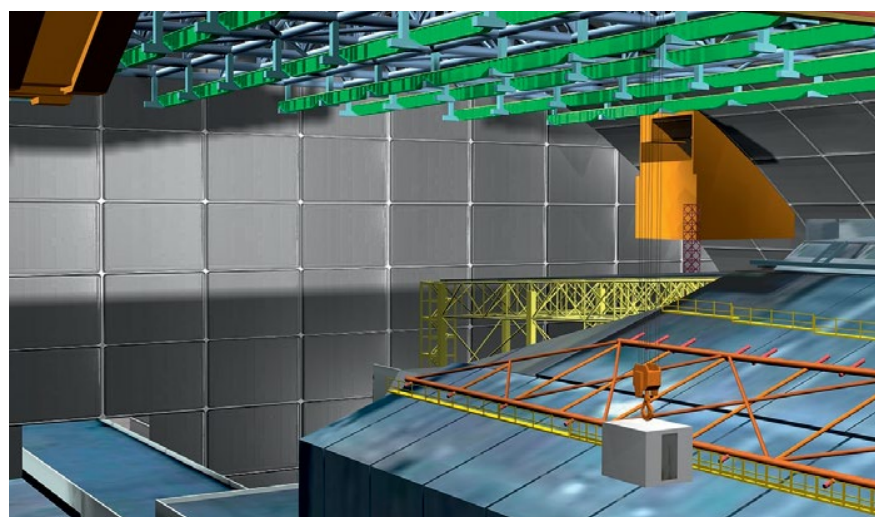

Fig. 3. The scheme of use of the cabin

The following basic design decisions of the shielded cabin are foreseen:

1. The cabin has a rectangular shape, equipped with a traverse for fastening.

2. The cabin does not have a door, but it is equipped with a doorway and a gate.

3. The cabin is equipped with a folding ladder for safe passage of the staff to roof and back. 
4. The interior surfaces of the cabin shall be made of materials that are easily deactivated.

5. The interior layout of the protective cabin is designed for seats for three persons (taking into account the use of their main and additional personal protective equipment) and provides for emergency evacuation in the event of failure of main cranes, as well as rails and safety belts for safe retention of personnel during displacements.

In the simulation of radiation conditions in which the protective cabin will be operated, the expert estimation method has been used to determine the value of gammaradiation at each stage of the cabin movement route. For calculation of the thickness of the cabin walls, the Microshield MS 5 software was used. Thus, it was found that the top of the cabin should be shielded with 15 $\mathrm{mm}$ of lead, side surfaces $-30 \mathrm{~mm}$, the floor $-25 \mathrm{~mm}$. The specified specification of wall thicknesses will provide an equivalent/or effective dose rate less than $25 \mathrm{mSv} / \mathrm{h}$ inside of the protective cabin, at its transportation along the route and in conditions when the equivalent/ or effective dose rate levels are higher than $0.5 \mathrm{~Sv} / \mathrm{h}$.

\section{Conclusions}

The practical experience of participation in projects on transformation of the Shelter object into an ecologically safe system has shown the effectiveness of using shielding as one of the most effective ways of protecting personnel.

The use of protective boxes and shielded cabins for personnel allows to reduce the equivalent dose rate in the workplace up to 20 times. In this case, the calculated values are in good agreement with the data obtained when the actual use of protection in the work areas.

The use of shielding lead to a significant reduction in the collective dose of radiation during the implementation of the Shelter object unstable structures stabilization. The "dose-cost-benefit" analysis showed the importance of applying protective measures in the workplace for highly qualified specialists (crane operators, welders, etc.).

It is shown that the use of special shielded cabins for personnel access to the work areas can significantly reduce the cost of the implementation of measures to dismantle unstable structures of the Shelter object.

\section{References}

1. SIP SKB02 WCD-EP 00200 / 02-88-02.01. SSE ChNPP. Shelter Implementation Plan on the Shelter Object. Cementation of the Base Soil, Taking into Account the Drilling of Wells with a Diameter of $150 \mathrm{~mm}$. Technology of Drilling Injection Wells and Cementation of the Soil Foundation. (in Russ.)

2. Strategy for transformation of the Shelter object into an ecologically safe system. Approved by the Interdepartmental Commission for the Integrated Solution of the Problems of the Chornobyl NPP dated on March 12, 2001, no. 2, 18 p. (in Ukr.)

3. SIP K 0401000 RSR002 03. Final Executive Report on Stabilization Measures (Safety Analyses Report). Shelter implementation plan on the Shelter object. 2018. (in Russ.)

4. Batiy V. G., Egorov V. V., Zakrevsky Yu. A., et al. (2000). Optimization of Shielding Using Experimental Data on the Angular Distributions of the Intensity of Gamma Radiation. Problemy Chornobylya [Problems of Chornobyl], vol. 9, pp. 53-55. (in Russ.)

5. Batiy V. G., Glebkin S. I., Yegorov V. V., et. al. (2004). Physical and Mathematical Simulation of Biological Shielding. Problems of atomic science and technology. Series "Nuclear physics investigations", vol. 44, no. 5, pp. 101-102.

6. Report on the Results of Studies of the Radiation Situation in the Areas of Work for Stabilization of the Building Structures of the Shelter Object. Shelter Implementation Plan. International Chernobyl Consortium - ICC (MK) JV. Chornobyl, 2002, 198 p. (in Russ.)

7. 301503.201.007-ZVSZ Report on correspondence with the requirements of sanitary legislation. Project for reconstruction of the Shelter object Chornobyl NPP in connection with the dismantling of a metal farm on the southern roof. Chornobyl: SSE ChNPP, 2016, Vol. 7. (in Ukr.)

\section{В. В. Єгоров, С. А. Паскевич, Л. І. Павловський, О. В. Балан}

Інститут проблем безпеки АЕС НАН Украӥни, вул. Кірова, 36а, Чорнобиль, 07270, Україна

\section{Досвід та перспективи використання екранування під час виконання робіт із перетворення об'єкта «Укриття» на екологічно безпечну систему}

Важливим заходом радіаційного захисту персоналу під час роботи в радіаційно небезпечних умовах обєєта «Укриття» $є$ проведення екранування в зонах виконання робіт. Інститут проблем безпеки АЕС НАН України виконав значний об’єм робіт з аналізу радіаційних умов та обгрунтування необхідності застосування заходів з екранування. Ці заходи були практично реалізовані під час 
виконання проектів зі стабілізації балок Б1 і Б2 та стабілізації нестабільних конструкцій об’єкта «Укриття», а також створення огороджувального контура нового безпечного конфайнмента. Також екранування використовувалось під час стабілізації опори балки «Мамонт», а також робіт із цементування грунтів у локальній зоні об’єкта «Укриття». Основним типом засобів екранування були захисні свинцеві екрани та захисні кабіни.

Застосування екранованих захисних кабін дало змогу зменшити рівні потужності експозиційної дози на робочих місцях від 5 до 25 разів.

Під час стабілізації західної частини об'єкта «Укриття» було збудовано спеціальну захисну стіну, що грала роль екрана для персоналу, який здійснював збирання металічних конструкцій підсилення. Рішення про створення захисної стіни з бетонних блоків було ухвалено на основі аналізу «доза - затрати - вигода». Розрахунками передбачалось, що захисна стіна мала знизити потік гамма-випромінювання в 2,5 раза, але фактично рівні ослаблення гамма-випромінювання знаходились в межах від 1,8 до 3,2 раза. У цілому проведення такого заходу було виправданим.

Використання екранування привело до зниження колективної дози опромінення під час стабілізації нестабільних конструкцій об’єкта «Укриття» на 1,1 Зв. При цьому було показано, що важливо реалізовувати заходи з екранування в місцях роботи спеціалістів високої кваліфікації (зварювальники, кранівники та ін.).

Проаналізовано доцільність використання спеціальних екранованих кабін для транспортування персоналу до зон виконання робіт під час демонтажу нестабільних конструкцій, що дасть змогу суттєво знизити рівні опромінення персоналу.
Ключові слова: радіаційний захист, екранування, об’єкт «Укриття», джерело випромінювання.

\section{В. В. Егоров, С. А. Паскевич, Л. И. Павловский, О. В. Балан}

Институт проблем безопасности АЭС НАН Украины, Чернобыль, ул. Кирова 36а, Чернобыль, 07270, Украина

\section{Опыт и перспективы использования экранирования при выполнении работ по преобразованию объекта «Укрытие» в экологически безопасную систему}

Проведен анализ эффективности использования защиты персонала от интенсивных источников ионизирующего излучения в зонах выполнения работ на объекте «Укрытие». Представлены данные о практическом применении защитных экранов при выполнении работ по стабилизации нестабильных конструкций объекта «Укрытие». Обоснованы модели применения специальных защитных кабин для работ по демонтажу конструкций объекта «Укрытие», которые планируется выполнять вскоре после ввода в эксплуатацию нового безопасного конфайнмента. Показано решающее значение использования экранирования для защиты персонала как одного из наиболее эффективных методов снижения коллективной дозы облучения.

Ключевые слова: радиационная защита, экранирование, объект «Укрытие», источник излучения.

Надійшла 20.02.2019

Received 20.02.2019 